\title{
An Effective and Concrete Way in Assessing the Learning Process by Using Market Media to Promote Local Wisdom
}

\author{
A R Lestari \\ Public Junior High School 1 Takeran, Magetan, Jawa Timur, Indonesia
}

\section{Article Info \\ Article history: \\ Received March 30, 2020 \\ Revised April 22, 2020 \\ Accepted April 24, 2020}

\section{Keywords:}

Effective way

Assessment

Curriculum-2013

Market media

Local wisdom

\begin{abstract}
The writing of this best practice aims to describe an effective and concrete way in assessing the 2013 curriculum by using market media to raise a local wisdom. According to the advice of the Minister of Education and Culture (MOEC), grade seven of science textbook, the 2013 curriculum (C13) is designed to strengthen student competencies in terms of knowledge, skills, and attitudes. As a competency-based curriculum, C13 emphasizes activity-based learning that aimed at facilitating students to obtain those skills. Therefore, assessments of learning must include attitudes, knowledge, and skills both during the process (formative) and at the end of the learning period (summative). This research was conducted in a public junior high school in Magetan, East Java, Indonesia. The geographical location reinforces the author to utilize a market as an effective and concrete media in conducting the expected assessment in C13. There are several dimensions of market structure that affect the behavior of market residents. Among the diversity of behavior also requires market residents in the ability dimensions of attitude, knowledge and skills. In addition, by using the market as a learning media, students are expected to have ideas to promote regional product commodities as well as to raise the local wisdom of their regions.
\end{abstract}

\section{INTRODUCTION}

Quoting from the regulation from Ministry of Education and Culture (MOEC) especially for grade seven of Science textbook, the 2013 Curriculum (C-13) is designed to strengthen student competency in terms of knowledge, skills and attitudes as a whole (Kemdikbud, 2015; 2016). The achievement process is conducted through learning a number of subjects that are arranged as a unit that mutually supports the achievement of these competencies. C13 is a competency-based curriculum that emphasizes activity-based learning that aimed at facilitating students to obtain attitudes, knowledge, and skills (Permendikbud, 2018). This regulation has implications for assessments that must include attitudes, knowledge, and skills both during the process (formative) and at the end of the learning period (summative) (Permendikbud, 2016). Therefore, it is expected that in C-13, all three assessments of these competencies will be carried out.

A routine agenda for five years in a row that author has been experienced, the author got an additional assignment as a District instructor or tutor where she had to do the C-13 implementation assistance to schools in Magetan District, part of East Java, Indonesia (see Figure 1). The assignment began in July as well as the target school began the C-13 in grade seven at the beginning of the school year. Automatically, the author's time was also greatly reduced because she had to leave school to carry out the assistance task. In this case, she was required to be very clever to get around and solved so that her task as a teacher to teach at her school is still going well. She have also to do three kinds of assessments as stipulated in 
Permendikbud No 23 of 2016, chapter VI article 12, namely the assessment of attitude, knowledge, and skills aspects (Permendikbud, 2016).

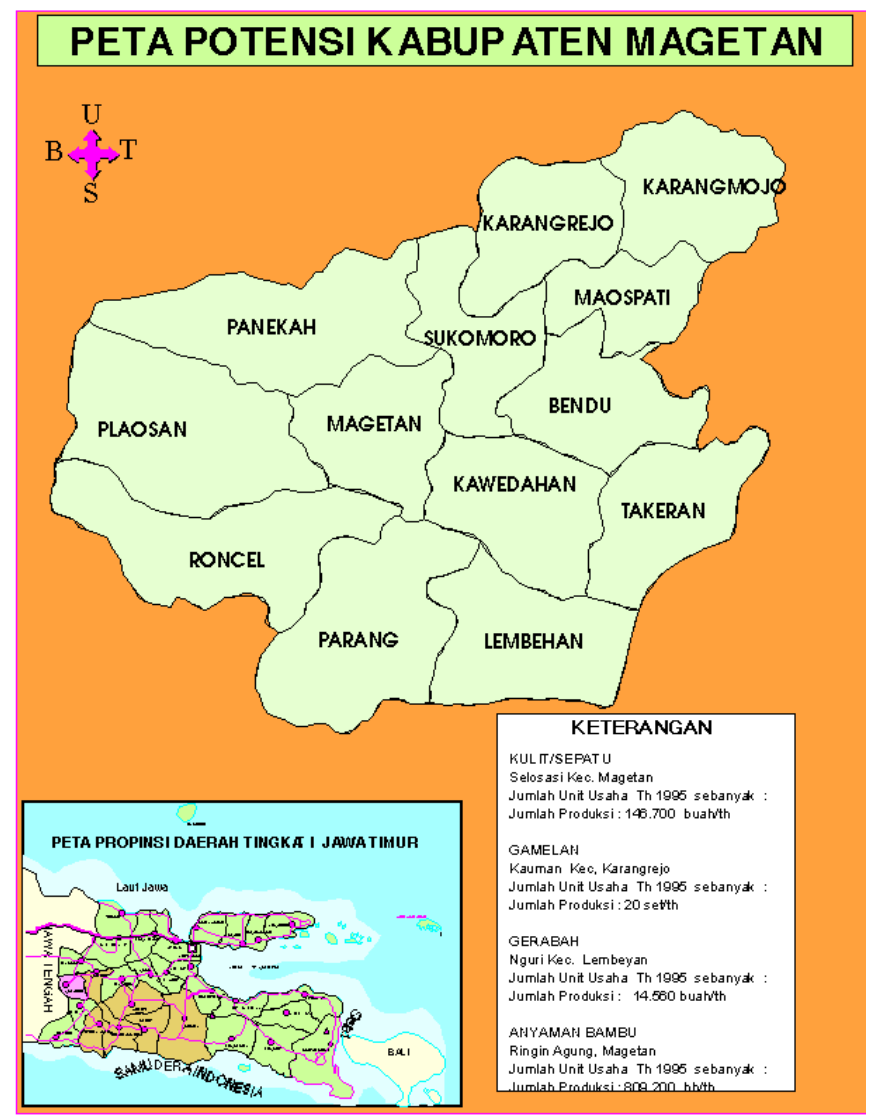

Figure 1. Map of the potential of the district of Magetan (eastjava.com, 2020)

Based on the author's experiences, in carrying out assistance to schools there were always questions from fellow teachers regarding the implementation of the C-13 assessment. It was very understandable because this was indeed something new among the teachers. Their questions varied, ranging from the technical implementation of the assessment, the form of the assessment to even the most effective and concrete ways or methods for carrying out the assessment. So far, what the author have done and knew from the implementation of C-13 assessment by fellow teachers, it only confined to the school environment. Assessment of attitude is carried out only when learning activities take place or sometimes outside the classroom. So, this kind of assessment is limited to students' attitudes to teachers, employees and fellow students. Likewise, the assessment of knowledge is only limited to answering questions both in the form of written questions or comments from the teacher and the assessment of skills is limited to skills related to the implementation of the practicum.

Geographically, the author's school is close to several traditional markets. There is a market, a village market which is located on the border with the city of Madiun where the author pass by every day when going to school. There is also a sub district market that is located on the edge of the highway and close to the district office. When the author left for work and at a glance, she observed the market activity. Sometimes she occasionally stops by after work because she buys something. The hustle and bustle of the market residents illustrates a situation that demands some competence, ranging from traders, buyers, parking attendants, sales tax takers, and freight transport services to public bathroom guards.

The behavior of the market residents is very diverse. There are several dimensions of market structure that affect the behavior of market residents. Among the diversity of 
behavior also requires market residents in the ability dimensions of attitude, knowledge and skills. This is the same as the standard assessment requirements that exist in the C-13. Based on the rationale above, the author optimizes the traditional market as a learning medium in the hope that students have ideas or ideas to raise the commodity of their regional products after seeing the goods being traded in the market; either marketing or packaging in other forms so that it has more selling value. It is endeavored that in the future students will be able to elevate the local culture or local wisdom. Departing from this in mind, the author tries to use the market as an effective and concrete way to assess the C-13 to raise local wisdom.

From the description in the background, the problem can be formulated as follows: What is the most effective and concrete way to assess the C-13 by using market media to promote local wisdom?. Starting from these problems, the author uses a strategy for the solution as follows:

By using the market as a very effective and concrete media in assessing the C-13 for grade seven even semester of science subject with topic of the Measurement and Classification of living things to raise local wisdom.

\section{BEST PRACTICE IMPLEMENTATION}

The use of markets as an effective and concrete media conduct a C-13 assessment Market is a place where there is a natural mechanism of exchange of goods and services that has been going on since the beginning of human civilization (Ningsih \& Kadarusman, 2008). Islam places the market in an important position in the economy. This is shown by the economic practice of the masses of the Messenger of Allah and Khulafaur Rasyidin, PostRasulullah SAW Leadership Time in that the market has a significant role.

In the market community, there is an interaction between the seller and the buyer where in both activities there must be some competencies that they must have so that the sustainability of activities in the market continues conducive. A market with heterogeneous occupants requires each market user to have some competence so that interaction within the community still exists.

There are several dimensions of market structure that affect the behavior of market residents. Among the diversity of behavior also requires market residents in the ability dimensions of attitude, knowledge and skills. This is the same as the demands of the assessment standards that exist in the C-13. The market is an effective and concrete media in carrying out the C-13 assessment. It is effective because in two hours of learning by using the market as a learning medium, students are able to work on several sheets of activity. Of course the teacher is also able to effectively carry out several assessments. It is concrete because it is a contextual learning where students observe in real terms the materials and tools available in the subject matter and are also directly involved in interacting with their surroundings even in a wider and diverse community.

\section{RESEARCH METHOD}

This best practice utilizes the implementation of problem solving strategies that uses procedure as follow.

\section{Planning Phase}

The planning phase includes six steps as follow:
a) Preparation of lesson plans as well as the preparation of student worksheets
b) Making an attitude assessment journal
c) Creation of a Knowledge assessment Format
d) Making Skills assessment format
e) Documentation tools
f) Provision of transportation 


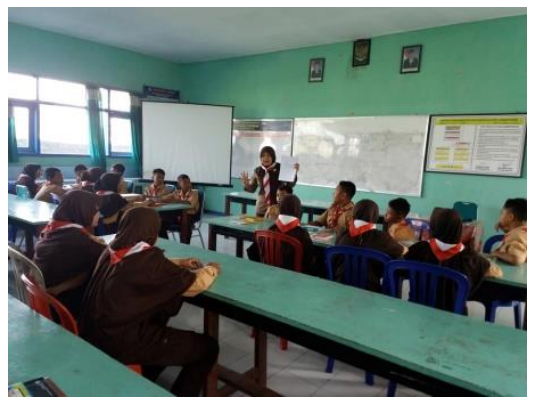

1. Initial explanation and coordination

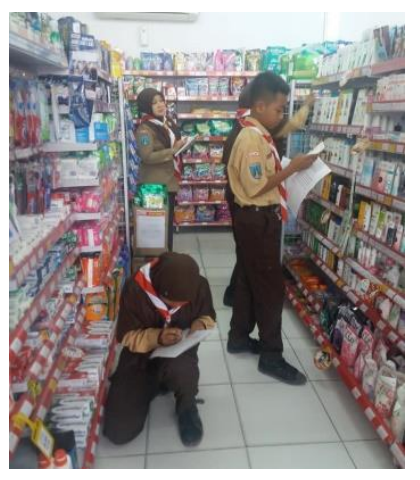

4. Counting measurement fraction
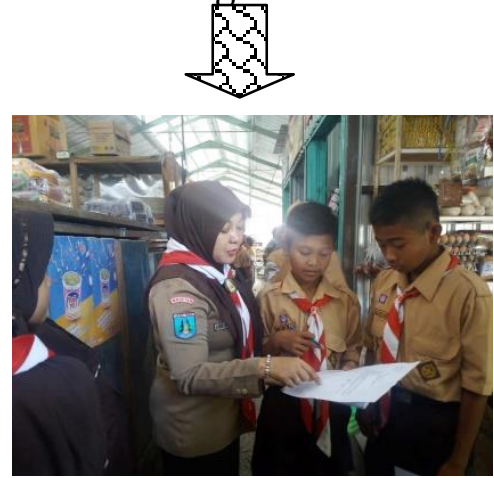

5. Filling the data of animal classification

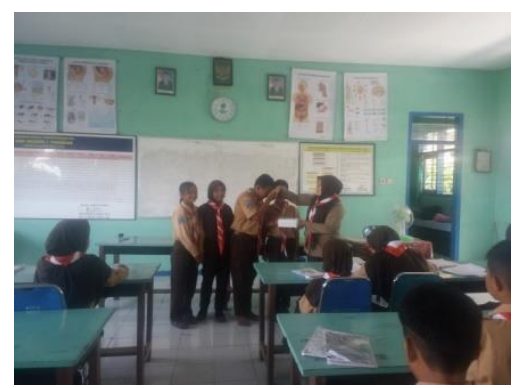

8. Giving a reward for the best group

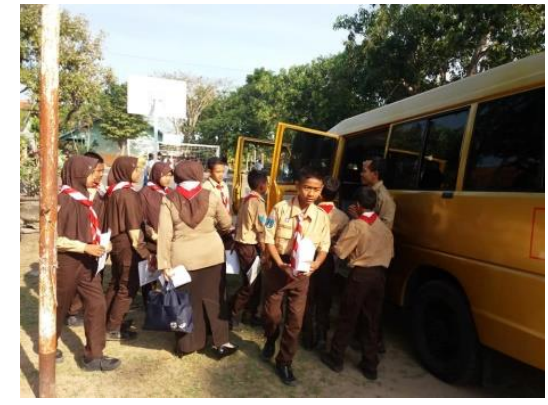

2. Preparation to market
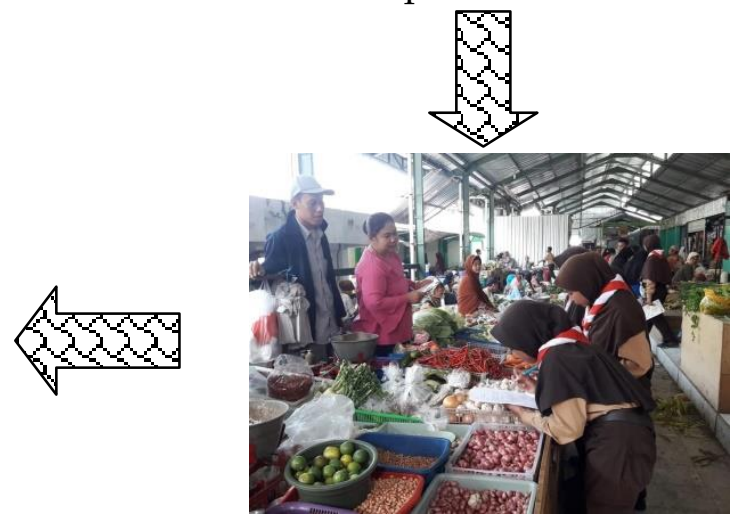

3. Filling the data of plant classification

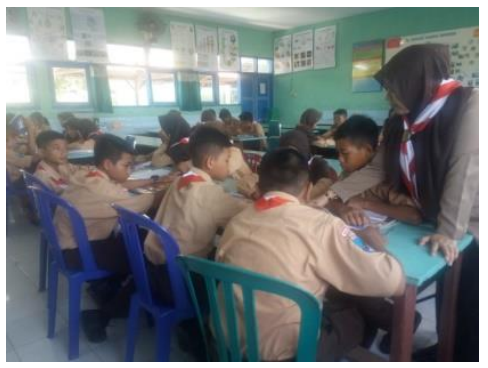

6. Group discussion

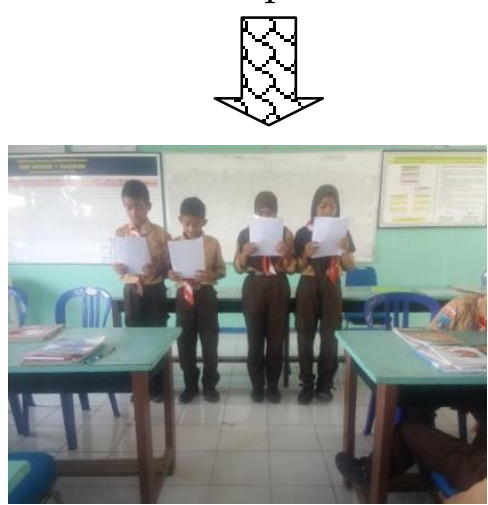

7. Group presentation

Figure 2. The sequence of learning process 
Figure 2 illustrates the detail of learning process sequence. The learning is started from initial explanation and coordination, then initial explanation and coordination. In the following step, students filling the data of plant classification and counting measurement fraction. The next step is filling the data of animal classification and group discussion. The last step is Group presentation and giving a reward for the best group.

\section{Implementation Stage}

In the implementation stage, there are eleven parts that students do as the following.

a) Activities carried out during science lessons during 2 hours of learning ( $2 \times 40$ minutes), precisely Saturday 15 September 2018. After formed learning groups begins with an explanation by the teacher about the learning steps to be carried out and the tasks which must be done by each group.

b) Division of tasks in groups

c) Depart to the market by using public transportation

d) After arriving at the market gather to ensure completeness group members were retired again

e) Students carry out their respective assignments by filling out worksheets, while the teacher evaluates attitudes and skills

f) After 30 minutes according to the agreed time gather again for back to school

g) Discussion in groups

h) Inter-group presentations

i) Conclusion.

j) Gift giving to the group with the best performance.

k) The teacher evaluates knowledge based on the results from the Sheet work done by students

\section{RESULTS AND DISCUSSION}

From the implementation of learning by using the market as a medium for assessing the C13, we get truly effective and concrete results. Within 30 minutes, the teacher was able to conduct an attitude assessment for each student in real interaction with a more diverse and diverse community. It was able to train students to live in society with a polite attitude. In the attitude assessment journal conducted by the teacher, more notes are obtained when learning using market media, rather than learning that is usually done in the classroom, including the attitude in driving (queuing when getting in and out of a vehicle, sitting in a vehicle according to the rules) helps cross a way for people who are old, and so on. This becomes the teacher's reference to do more guidance for students who still need guidance. For students who are able to behave properly is an example for other students.

For skills assessment, the data obtained is more varied than just the assessment notes in the skills assessment format. In the skills assessment format prepared by the teacher is the communication skills with fellow market users and the skills in sorting and returning goods have apparently developed in a number of skills assessments, including the skills of arranging and grouping goods to help traders.

Effective because in one activity interacting with sellers and with people who are in the market, to fill out their worksheets or their desire to buy an item students can already show the ability of the dimensions of their skills. Concrete because everything is implemented in real terms, students actually do real practice directly the ability of their skills.

Whereas for the assessment of knowledge obtained better assessment results because so far students are usually only limited to working on the problem just by imagining the object or viewing images through the LCD. But by using market media students can see firsthand their original objects making it easier to instill better concepts, for example, regarding plant 
classification and animal classification, so far only observing and classifying plants and animals that are around the school. Of course, the amount will be very limited.

By going to the market, students will find a wider variety of plants and animals, so they have the ability to classify better. For materials such as measuring devices, so far students have only been shown a number of measuring devices owned by the school, of course incomplete, such as the duck scales and hybrid scales that schools rarely have. Usually to dissolve the teacher display images through the LCD, even then not all schools are able to do because related to LCD that not all schools have enough. However, by using the market as a learning medium, students are able to concretely see the various kinds of measuring devices making it easier for them to add knowledge more easily. Likewise with the material to calculate the volume ratio of a product, students are usually only presented with questions in the form of words and numbers, or maybe also in the form of pictures. So in calculating the comparison only uses the shadow of the object. By jumping directly into the market students can directly see the objects that will be calculated in comparison. This makes it easy to plant their concepts to calculate the volume ratio because objects can be seen clearly.

In developing ideas or ideas that arise from students about efforts to increase the commodity of regional products so as to be able to elevate the local wisdom of their area, there are student records about these ideas. After observing the goods that are bought and sold in the market from students, ideas or ideas arise to raise local wisdom by increasing the commodity yields, including making mango chips with various flavors, making oil from the oil content contained in Pamelo orange peels, making special quality tempeh for sufferers of malnutrition, tiwul with various flavors and so on.

\section{Constraints Faced}

1) Not all the diversity of people in the market can accept the presence of students to study, especially if students only ask for permission and just asking about the merchandise without buying it.

2) If the market is far from school it will reduce more lesson time much on the way and requires more transportation costs big.

3) Market conditions are broader than the class with many shanties extra student supervision is required.

\section{Supporting Factors}

1) The existence of the market is not too far from the school so only takes about 5 minutes and transportation costs are not too much expensive.

2) People in the cooperative market welcome the presence of students to learn.

3) Students are compact and obey the rules so that activities can run smoothly.

\section{Alternative Development}

1) Because markets can be multidimensional and multi-functional, activities learning can be developed for material in different chapters.

2) To facilitate supervision of students can be assisted by other teachers as a form of collaboration between subjects with the interests of the pursuit different. 
Studies in Learning and Teaching (SiLET)

Vol.1, No.1, April 2020, pp. 41-51

ISSN: 2722-1857

\section{Illustration of Student worksheet}

1. Comparison in measurements

\section{Lembar Kerja Siswa}

$\mathrm{LK} 1.1 .2 / \mathrm{IPA} / \mathrm{VII} / 1$

Nama Kelompok : Albet ens tin

Lokasi : Swalayan Sumber Urip, Kec. Takeran

\section{"Perbandingan dalam pengukuran"}

I. Alat dan bahan

- Buku Siswa

- Lembar Kerja

- Ballpoint/Pulpen

II. Cara Kerja

1. Dengan pendampingan gurumu pergilah ke swalayan terdekat dari sekolahmu!

2. Bersama kelompokmu amatilah macam-macam barang yang dijual di swalayan tersebut!

3. Carilah barang dengan jenis yang sama dengan perbandingan harga yang berbedal

4. Cermati perbedaan tersebut, kemudian hitunglah lebih murah yang mana dari keduanya!

5. Masukkan data pada tabel berikut dan hitunglah perbandingannya!

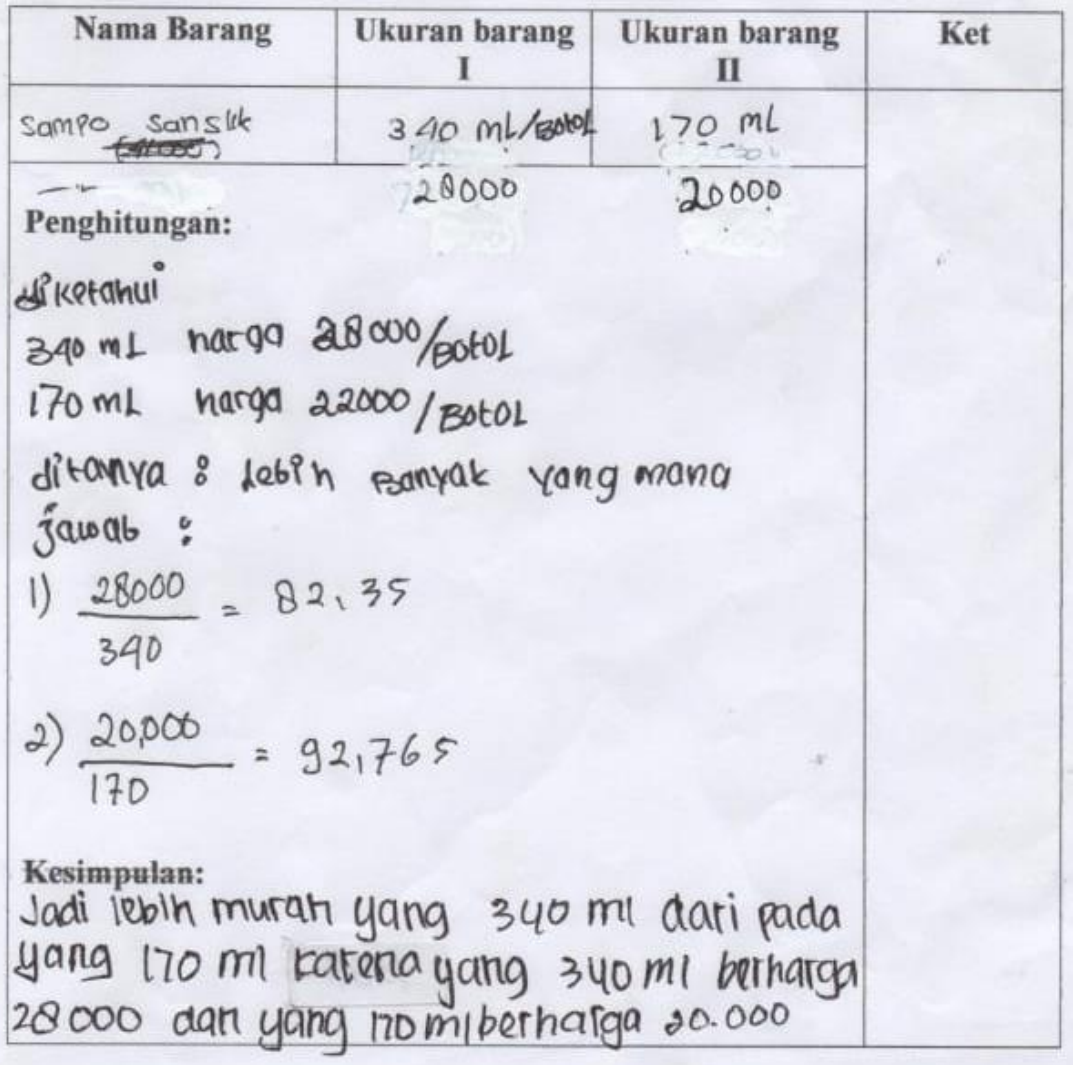

Figure 3. An example of student worksheet: comparison in measurements 


\section{Animal classification}

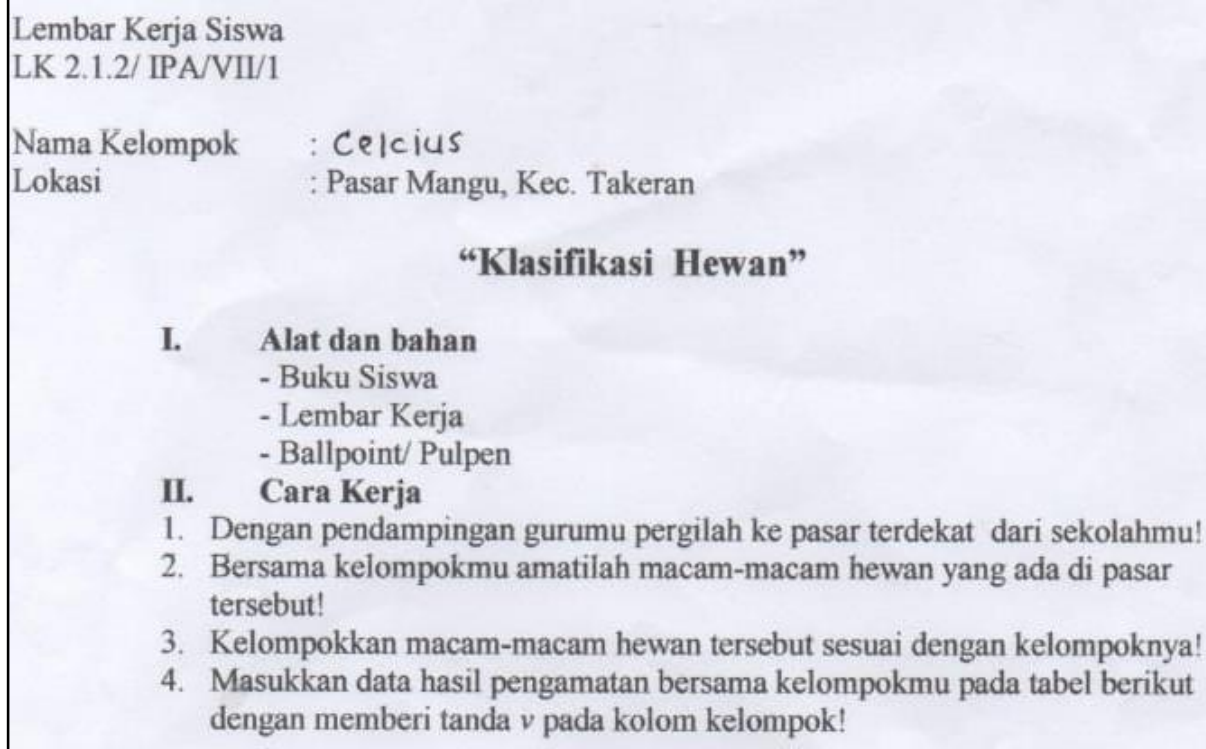

"Klasifikasi Hewan"

I. Alat dan bahan

- Buku Siswa

- Lembar Kerja

- Ballpoint/ Pulpen

II. Cara Kerja

1. Dengan pendampingan gurumu pergilah ke pasar terdekat dari sekolahmu!

2. Bersama kelompokmu amatilah macam-macam hewan yang ada di pasar tersebut!

3. Kelompokkan macam-macam hewan tersebut sesuai dengan kelompoknya!

4. Masukkan data hasil pengamatan bersama kelompokmu pada tabel berikut dengan memberi tanda $v$ pada kolom kelompok!

\begin{tabular}{|c|c|c|c|c|c|}
\hline \multirow{2}{*}{ No } & \multirow{2}{*}{ Nama hewan } & \multicolumn{3}{|c|}{ Kelompok } & \multirow[t]{2}{*}{ Keterangan } \\
\hline & & Ternak & Piaraan & Liar & \\
\hline 1 & KUCING & & & $\sqrt{ }$ & \\
\hline 2 & buning Jalak & & $\checkmark$ & & \\
\hline 3 & burung dara & & $\checkmark$ & & \\
\hline 4 & ikan gurame & $\checkmark$ & & & \\
\hline 5 & itan lele & $\checkmark$ & & & \\
\hline 6 & I kan gabus & $\checkmark$ & & & \\
\hline 7 & ayam & $\checkmark$ & & & \\
\hline 8 & ikan teri & $v$ & & & \\
\hline 9 & 1 Kan nila & $\checkmark$ & & & \\
\hline 10 & cumicumi & $\checkmark$ & & & \\
\hline 11 & bebek & 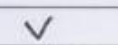 & & & \\
\hline 12 & Sapi & $\checkmark$ & & & \\
\hline 13 & kambina & V & & & \\
\hline 14 & burung kacer & $\checkmark$ & & & \\
\hline 15 & burung kutiang & $V$ & & & \\
\hline 16 & men thok & $v$ & & & \\
\hline 17 & torogkol & $v$ & & & \\
\hline 18 & IKan Patin & $v$ & & & \\
\hline 19 & burang Pentet & 4 & $\checkmark$ & & \\
\hline 20 & Lebah & & & $v$ & \\
\hline 21 & kupu-kupu & & & $\checkmark$ & \\
\hline 22 & Burung tipit & $\checkmark$ & $v$ & & \\
\hline 23 & kan bader & $\checkmark$ & & & \\
\hline
\end{tabular}

Figure 4. An example of student worksheet: animal classification 
Studies in Learning and Teaching (SiLET)

Vol.1, No.1, April 2020, pp. 41-51

ISSN: 2722-1857

3. Plant Classification

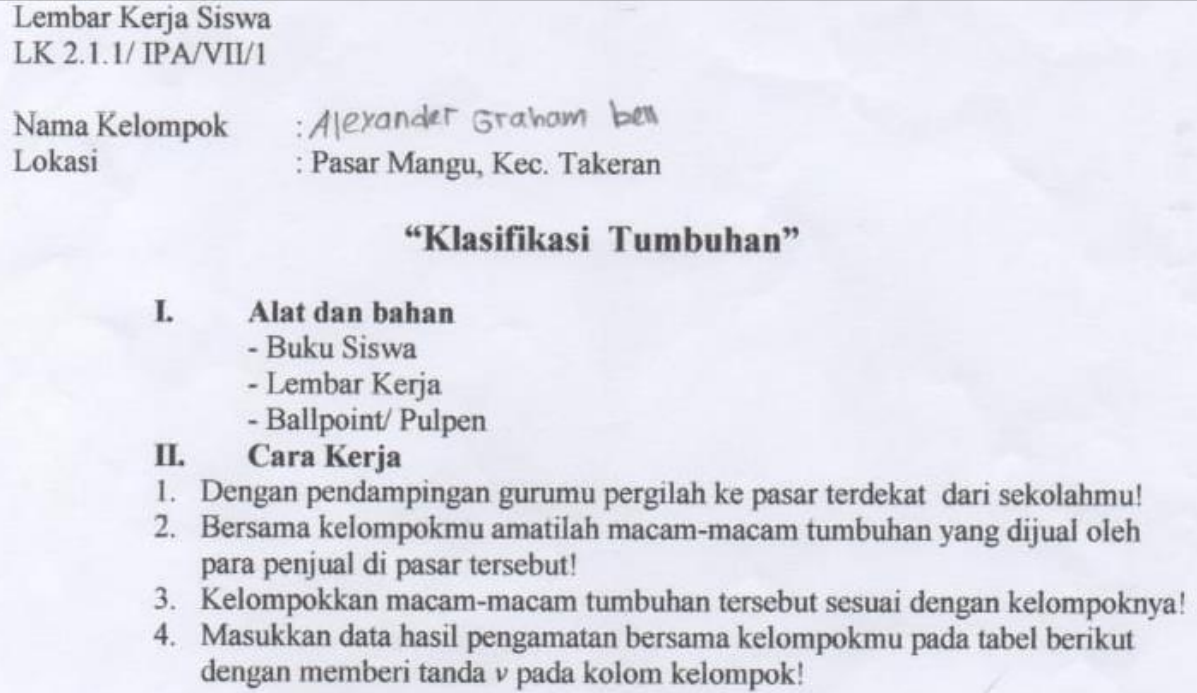

"Klasifikasi Tumbuhan"

I. Alat dan bahan

- Buku Siswa

- Lembar Kerja

- Ballpoint/ Pulpen

II. Cara Kerja

1. Dengan pendampingan gurumu pergilah ke pasar terdekat dari sekolahmu!

2. Bersama kelompokmu amatilah macam-macam tumbuhan yang dijual oleh para penjual di pasar tersebut!

3. Kelompokkan macam-macam tumbuhan tersebut sesuai dengan kelompoknya!

4. Masukkan data hasil pengamatan bersama kelompokmu pada tabel berikut dengan memberi tanda $v$ pada kolom kelompok!

\begin{tabular}{|c|c|c|c|c|c|}
\hline \multirow[b]{2}{*}{ No } & \multirow[b]{2}{*}{ Nama tumbuhan } & \multicolumn{3}{|c|}{ Kelompok } & \multirow{2}{*}{ Keterangan } \\
\hline & & Sayuran & $\begin{array}{c}\text { Buah- } \\
\text { buahan }\end{array}$ & $\begin{array}{c}\text { Kebutuhan } \\
\text { pokok }\end{array}$ & \\
\hline 1 & Sowp putin & $\checkmark$ & & 工 & \\
\hline 2 & Sela do & $\checkmark$ & & & \\
\hline 3 & Bayam & $\checkmark$ & & & \\
\hline 4 & Tomat & $\checkmark$ & 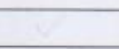 & & \\
\hline 5 & Brocclp & $\checkmark$ & & & \\
\hline 6 & wortel & $\checkmark$ & 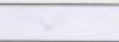 & & \\
\hline 7 & pisang & & $\checkmark$ & & \\
\hline 8 & Semangka & & $r$ & & \\
\hline 9 & Timun & $\checkmark$ & & & \\
\hline 10 & Beras & & & $\checkmark$ & \\
\hline 11 & Mangga & & $\checkmark$ & & \\
\hline 12 & melon & & $\checkmark$ & & \\
\hline 13 & pete & $\checkmark$ & & & \\
\hline 14 & Jahe & & & $\checkmark$ & \\
\hline 15 & Kunit & & & $\checkmark$ & \\
\hline 16 & seledri & $\checkmark$ & & & \\
\hline 17 & Bawargy bomba? & 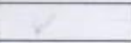 & & $\checkmark$ & \\
\hline 18 & $60 \mathrm{mbas}$ & $\checkmark$ & & z & \\
\hline 19 & Timun & $\checkmark$ & & & \\
\hline 20 & Bawang pre & $v$ & & & \\
\hline 21 & Jagung & $\checkmark$ & & & \\
\hline 22 & Jambu & & $\checkmark$ & & \\
\hline 23 & Bawoang merah & 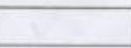 & & $\checkmark$ & \\
\hline 24. & jeruk & $y$ & $\checkmark$ & & \\
\hline 25. & pepaya & 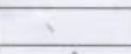 & $\checkmark$ & & \\
\hline
\end{tabular}

Figure 5. An example of student worksheet: plant classification 
4. Various measuring devices and ideas about local wisdom

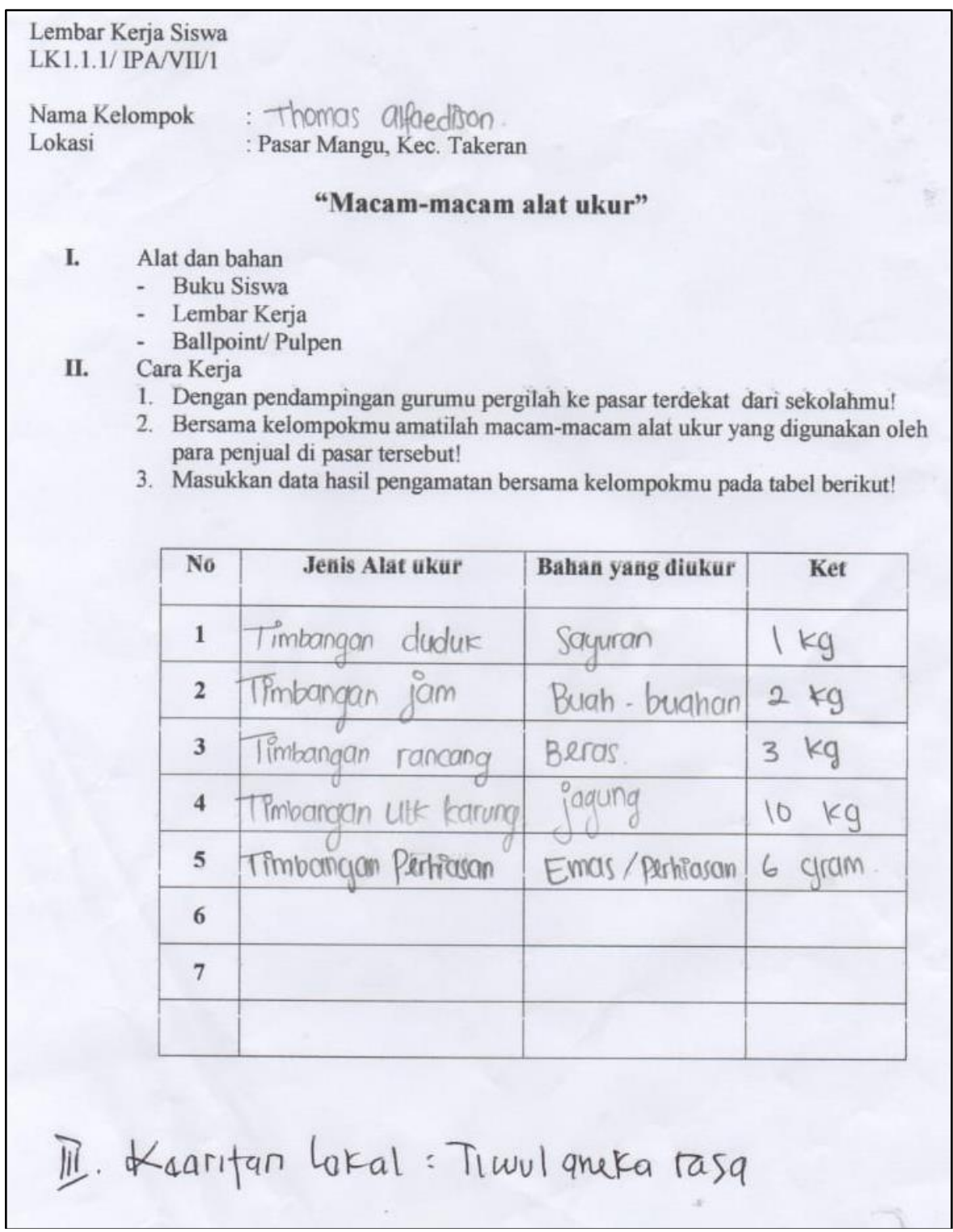

Figure 6. An example of student worksheet: various measuring devices and ideas about local wisdom

\section{CONCLUSION}

From the description of the implementation and results and discussion, it can be concluded that an effective and concrete way to assess the C-13 subject to the measurement and classification of living organisms is to use market media. Therefore, it can be used as an alternative to assessing the C-13 in different chapters and subjects; of course, it still has to do with the market. In addition to the importance of assessment can also be developed to bring up ideas or ideas from students about efforts to improve the local wisdom of their area.

To be more effective and efficient in carrying out the assessment process, it can be collaborated with other related subjects. Therefore, the role of subject teacher deliberations, Musyawarah Guru Mata Pelajaran (MGMP) in schools should be optimized so that better coordination occurs. 


\section{ACKNOWLEDGEMENTS}

Thank you for all students of Public Junior High School (SMPN) 1 Takeran, Magetan, East Java, Indonesia who contribute to this best practice.

\section{REFERENCES}

Eastjava.com. (2020). Peta potensi kabupaten Magetan. Retrieved from https://www.eastjava.com/plan/peta/html/pkab-magetan.html

Kemdikbud. (2015). Panduan penilaian untuk Sekolah Menengah Pertama Direktorat Pembinaan Sekolah Menengah Pertama [Assessment guide for Junior High Schools Directorate of Middle School Development]. Jakarta: Direktorat jendral Pendidikan Dasar dan Menengah.

Kemdikbud. (2016). Panduan penilaian oleh pendidik dan satuan pendidikan Sekolah Menengah Pertama [Guidance assessment by educators and Secondary School Education Units]. Jakarta: Direktorat Pembinaan Sekolah Menengah Pertama, Direktorat jendral Pendidikan Dasar dan Menengah.

Permendikbud no 23. (2016). Standar penilaian pendidikan [Educational assessment standards]. Jakarta: Kemdikbud.

Permendikbud no 37. (2018). Perubahan atas Peraturan Menteri Pendidikan dan Kebudayaan no 24 tahun 2016 tentang Kompetensi Inti dan Kompetensi Dasar pelajaran pada Kurikulum 2013 pada Pendidikan Dasar dan Pendidikan Menengah [Amendments to the Minister of Education and Culture Regulation No. 24 of 2016 concerning Core Competencies and Basic Competencies of lessons in the 2013 Curriculum on Basic Education and Secondary Education]. Jakarta: Kemdikbud.

Ningsih, S. A., \& Kadarusman, Y. B. (2008). Teori ekonomi mikro. Yogyakarta: BPFE.

Corresponding Author:

Anik Rofaida Lestari

Teacher, Public Junior High School 1 Takeran

Magetan, East Java, Indonesia

Email: rofaidalestari@gmail.com 